\title{
BIOLOGICAL ACTIVITY OF MINIMAL DOSE OF AEROSOLIZED INTERFERON- $\alpha$ IN MALE ALBINO RATS
}

\author{
Khalil A. El-Halfawy ${ }^{1}$, Shaden M. Hanafy ${ }^{1}$, Bahgat A. EL-Fiky ${ }^{2}$ and Hassan M. Hassan ${ }^{1}$
}

${ }^{1}$ Molecular Biology Department, Genetic Engineering and Biotechnology Institute, University of Sadat City, Egypt

${ }^{2}$ Animal Biotechnology Department, Genetic Engineering and Biotechnology Institute, University of Sadat City, Egypt.

\begin{abstract}
Buffy coat leukocytes Interferon- $\alpha$ (IFN- $\alpha$ ) is a leucocyte-derived cytokine with pleiotropic effects on the cells of the immune system, including the ability to promote viral and microbial killing. Five batches of buffy coat leukocytes IFN- $\alpha$ were prepared and purifiied from five male buffalos under the same conditions of collections ; before,during and after slaughter. Three IFN- $\alpha$ doses; 200.500 and $1000 \mathrm{IU}$ were prepared. The present study was designed to evaluate the biologically active dosage of aerosolized buffy coat leukocytes IFN- $\alpha$, in male albino rats. Four healthy groups were included: Group 1 (control, $n=10)$ received 0 IFN- $\alpha$,Group $2(n=10)$ received 200 IU IFN- $\alpha$, Group 3 received $500 \mathrm{IU}$ and Group(4) received $1000 \mathrm{IU} /$ day in order to determine the minimal IFN- $\alpha$ dose able to induce biological effects without side-effects. Result data showed that 500 IFN- $\alpha$ IU/ day for five days induced a significant biological activity, increasing serum levels of biochemical, hematological and IFN- $y$ levels. It is concluded that aerosolized IFN- $\alpha$ administration to the lung is well-tolerated at biologically active doses.
\end{abstract}

Keywords: Buffy Coat Leukocyte IFN- $\alpha$, biochemical, hematological parameters and IFN- $\gamma$

\section{INTRODUCTION}

Interferons alpha are pleiotropic cytokines belonging to the type I IFN family, originally described for their antiviral activity. IFN- $\alpha$ can induce multiple biological effects, including induction / promotion of apoptosis and inhibition of cell growth. In addition, these cytokines promote the differentiation and activity of host immune cells. Several studies have shown that IFN- $\alpha$ can induce the rapid differentiation of monocytes into highly activated dendritic cells (DCs)which can play a role in the generation of antitumor T-cell immunity (Rizza et al., 2010).In response to interferon, cells produce large amounts of an enzyme known as protein kinase $\quad R(P K R)$. This enzyme phosphorylates a protein known as elF-2 in response to new viral infections; the phosphorylated elF-2 forms an inactive complex with another protein, called elF2B, to reduce protein synthesis within the cell. Another cellular enzyme, RNAse L-also induced by interferon action-destroys RNA within the cells to further reduce protein synthesis of both viral and host genes. Inhibited protein synthesis destroys both the virus and infected host cells. In addition, interferons induce production of hundreds of other proteins-known collectively as interferon-stimulated genes (ISGs)-that have roles in combating viruses (Hermant and Michiels, 2014). Another function of interferons is to upregulate major histocompatibility complex molecules, MHC I and MHC II, and increase immunoproteasome activity. Higher MHC I expression increases presentation of viral peptides to cytotoxic $T$ cells, while the immunoproteasome processes viral peptides for loading onto the MHC I molecule, thereby increasing the recognition and killing of infected cells. Higher MHC II expression increases presentation of viral peptides to helper $\mathrm{T}$ cells; these cells release cytokines that signal to and coordinate the activity of other immune cells. Interferons, such as interferon- $y$, directly activate other immune cells, such as macrophages and natural killer cells. (Hall et al., 2008). In a T cell-transfer model of colitis, treatment with a TLR9 ligand in the absence of type I IFN signaling failed to induce functionally suppressive CD4+ $\mathrm{CD} 62 \mathrm{~L}+\mathrm{T}$ cells, whereas pretreatment of the 
donor mice with recombinant IFN $\beta$ and subsequent $T$ cell transfer resulted in reduced intestinal inflammation and decreased secretion of pro-inflammatory cytokines (Hofmann et al., 2010). Indeed, a role for type I IFNs in TLR9 induced protec $\neg$ tion in T cell-dependent colitis was previously shown in germ-free mice; in this study, type I IFNs were shown to induce the expression of regulatory markers on CD4+CD62L+ $T$ cells (Bleich et al., 2009). Type I IFNs have been shown to have an important role in the differentiation of both CD4+ and CD8+ T cells. Initial studies found that IL 12 signalling in CD4+ T cells and the subsequent activation of STAT4, which in turn promotes $\mathrm{T}$ helper 1 (TH1) cell differentiation (Szabo et al., 2002). However, type I IFNs regulate $\mathrm{TH} 1$ cell differentiation and effector functions in vivo by synergizing with other cytokines, such as IL 18 and IL 21 (Huber and Farrar, 2011).

\section{MATERIALS AND METHODS.}

Leukocytes IFN- $\alpha$ preparation.Five blood batches were collected under veterinary supervision and transferred in sterile closed bags containing sodium phosphate dextrose anticoagulant to Animal Biotechnology lab at Genetic Engineering and Biotechnology Research Institute, University of Sadat City within 2 hours in ice pages for processing under aseptic conditions. Blood was removed from pages to graduated cylinder to measure volume before dilution with phosphate buffer saline solution. Buffy coat leukocytes were separated by combining diluted cells with hydroxy ethyl starch at a volume ratio $2: 1$.Buffy coat leukocytes were counted and cell viability determined before resuspended in buffy coat leukocyte medium and induction with NDV for interferon production according to the method of Foster (2000). Crude interferon was precipitated in the presence of $\mathrm{KSCN}$ at $\mathrm{pH}$ 3.5 then dissolved in acid ethanol and impurities and selectively precipitated by raising the $\mathrm{pH}$ then precipitated from the ethanolic solution around neutrality and concentrated according to the method of Cantell \& Hirvonen (1977). Concentrated preparations were titrated using WISH cell line and VSV virus to determine TCID 50 and its IU units according to the Medical
Research Council standard for leukocyte interferon / ml. Expermintal study. Forty adult albino rates were used in the study To dilute IFN- $\alpha, \quad 0.9 \% \quad \mathrm{NaCl}$ solution was employed.IFN- $\alpha$ was given in a solution of 1 $\mathrm{mg} / \mathrm{mL}$ animal albumin. Inhalation Study. IFN- $\alpha$ was given in a dose inhalation trial at 0 dose $(n=10), 200$ IFN- $\alpha$ IU $(n=10), 500$ IFN- alU $(n=10)$ and 1000 IU $(n=10) /$ days for 5 days of administration.

Inhalation of IFN- $\alpha$ was given by Nebulizer air compressor (Model:CN01)

Sinkan/Ankara. Blood samples were taken to be tested $24 \mathrm{~h}$ after the fifth dose. Biochemical study.

Assay of Haemoglobin Level:Haemoglobin concentration was determined by using kit supplied by Randox Company according to the method of Tiez (1976). Total protein: determined using total protein Kit (Biuret Method) in Serum and Plasma according to Doumas, (1975) Determination of Albumin: measured according to the instruction manual of Rat Albumin, ELISA Kit Cat. No. 6400, alpha diagnostic international, USA.Globulins: measured by RAT GC- Globulins ELISA test kit (Life Diagnostics, Inc., Catalog Number: 4100-2) according to Amacher et.al .,2005. Total cholesterol assessment:: measured according to Young et al. (2001) Urea assessment: measured by Colorimetric Assay Kit (BioVision, USA, Catalog \#K375100) Uric acid assessment: measured by Uric acid assay kit (Bioassay,USA). Interferon- $\boldsymbol{Y}$ Assay: Interferon- $\gamma$ assayed using Pig Interferon $\alpha$ (IFN- $\alpha)$ ELISA Kit(MBS700009,USA).

\section{RESULTS AND DISCUSSION}

Crude interferon derived from buffy coat leukocytes separated from male Buffalos is precipitated in the presence of $\mathrm{KSCN}$ at $\mathrm{pH}$ 3.5 then dissolved in acid ethanol and impurities selectively precipitated by raising the $\mathrm{pH}$. Interferon is precipitated from the ethanolic solution around neutrality and concentrated. Concentrated preparations were titrated using WISH cell line and VSV virus to determine TCID 50 and its IU units according to the Medical Research Council standard for leukocyte interferon / $\mathrm{ml}$. The yield batch is shown in table(1). 
Table (1): IFN- $\alpha$ yield in each batch of blood samples determined by TCID 50 activity.

\begin{tabular}{|c|c|c|c|c|}
\hline & Batch No. & $\begin{array}{l}\text { Total Blood } \\
\text { Volume } \\
\text { /ml }\end{array}$ & $\begin{array}{c}\text { Total } \\
\text { Leukocytes } \\
\end{array}$ & $\begin{array}{l}\text { IFN- } \alpha \text { yield } \\
\text { IU/ Sample }\end{array}$ \\
\hline \multirow{3}{*}{ B-1 } & Before slaughter & 250 & $1.0 \times 10^{8}$ & $2.3 \times 10^{8}$ \\
\hline & $\begin{array}{c}\text { During slaughter stage- } \\
1\end{array}$ & 250 & $1.2 \times 10^{8}$ & $2.5 \times 10^{8}$ \\
\hline & $\begin{array}{l}\text { During slaughter } \\
\text { stage-2 }\end{array}$ & 250 & $0.9 \times 10^{8}$ & $2.12 \times 10^{8}$ \\
\hline \multirow{3}{*}{ B-2 } & Before slaughter & 250 & $1.1 \times 10^{8}$ & $2.4 \times 10^{8}$ \\
\hline & $\begin{array}{c}\text { During slaughter stage- } \\
1\end{array}$ & 250 & $1.3 \times 10^{8}$ & $2.48 \times 10^{8}$ \\
\hline & $\begin{array}{l}\text { During slaughter stage- } \\
2\end{array}$ & 250 & $1.0 \times 10^{8}$ & $2.21 \times 10^{8}$ \\
\hline \multirow{3}{*}{ B-3 } & Before slaughter & 250 & $1.2 \times 10^{8}$ & $2.35 \times 10^{8}$ \\
\hline & During Sluphting-1 & 250 & $1.35 \times 10^{8}$ & $2.4 \times 10^{8}$ \\
\hline & During Sluphting-2 & 250 & $0.98 \times 10^{8}$ & $2.22 \times 10^{8}$ \\
\hline \multirow{3}{*}{ B-4 } & Before slaughter & 250 & $1.23 \times 10^{8}$ & $2.32 \times 10^{8}$ \\
\hline & During slaughter stage- & 250 & 1. $38 \times 10^{8}$ & $2.4 \times 10^{8}$ \\
\hline & $\begin{array}{l}\text { During slaughter stage- } \\
2\end{array}$ & 250 & $1.1 \times 10^{8}$ & $2.28 \times 10^{8}$ \\
\hline \multirow{3}{*}{ B-5 } & Before slaughter & 250 & $1.25 \times 10^{8}$ & $2.45 \times 10^{8}$ \\
\hline & $\begin{array}{c}\text { During slaughter stage- } \\
1\end{array}$ & 250 & $1.32 \times 10^{8}$ & $2.5 \times 10^{8}$ \\
\hline & $\begin{array}{l}\text { During slaughter stage- } \\
\qquad 2\end{array}$ & 250 & $1.1 \times 10^{8}$ & $2.18 \times 10^{8}$ \\
\hline
\end{tabular}

Table(2): Effect of IFN- $\alpha$ Inhalation at different doses on Biochemical parameters

\begin{tabular}{|c|c|c|c|c|}
\hline $\begin{array}{c}\text { Biochemical } \\
\text { Prameters }\end{array}$ & Control & $\begin{array}{c}\text { IFN- } \alpha \\
(\mathbf{2 0 0} \text { IU) }\end{array}$ & $\begin{array}{c}\text { IFN- } \alpha \\
\mathbf{( 5 0 0 ~ I U ) ~}\end{array}$ & $\begin{array}{c}\text { IFN- } \alpha \\
(\mathbf{1 0 0 0} \text { IU) }\end{array}$ \\
\hline $\begin{array}{c}\mathrm{Hb} \\
(\mathrm{g} / \mathrm{ml})\end{array}$ & $14.25 \pm 0.21^{\mathrm{a}}$ & $14.95 \pm 0.17^{\mathrm{a}}$ & $15.63 \pm 0.21^{\mathrm{a}}$ & $\begin{array}{c}16.25 \pm 0.3 \\
3^{\mathrm{a}}\end{array}$ \\
\hline $\begin{array}{c}\text { Total protein } \\
(\mathrm{g} / \mathrm{dl})\end{array}$ & $6.34 \pm 0.01^{\mathrm{a}}$ & $6.95 \pm 0.19^{\mathrm{a}}$ & $7.40 \pm 0.14^{\mathrm{a}}$ & $7.85 \pm 0.17^{\mathrm{a}}$ \\
\hline $\begin{array}{c}\text { Alb } \\
(\mathrm{g} / \mathrm{dl})\end{array}$ & $2.75 \pm 0.12^{\mathrm{a}}$ & $3.53 \pm 0.28^{\mathrm{a}}$ & $3.80 \pm 0.08^{\mathrm{a}}$ & $4.28 \pm 0.17^{\mathrm{a}}$ \\
\hline $\begin{array}{c}\text { Globulins } \\
(\mathrm{g} / \mathrm{dl})\end{array}$ & $3.25 \pm 0.13^{\mathrm{a}}$ & $3.87 \pm 0.09^{\mathrm{a}}$ & $4.20 \pm 0.14^{\mathrm{a}}$ & $4.75 \pm 0.06^{\mathrm{a}}$ \\
\hline $\begin{array}{c}\text { Total cholesterol } \\
(\mathrm{mg} / \mathrm{dl})\end{array}$ & $47.25 \pm 0.13^{\mathrm{a}}$ & $47.70 \pm 0.22^{\mathrm{ab}}$ & $48.40 \pm 0.13^{\mathrm{a}}$ & $\begin{array}{c}49.00 \pm 0.1 \\
8^{\mathrm{a}}\end{array}$ \\
\hline $\begin{array}{c}\text { Urea } \\
(\mathrm{mg} / \mathrm{dl})\end{array}$ & $34.23 \pm 0.17^{\mathrm{a}}$ & $35.10 \pm 0.24^{\mathrm{a}}$ & $36.28 \pm 0.15^{\mathrm{a}}$ & $\begin{array}{c}37.55 \pm 0.1 \\
3^{\mathrm{a}}\end{array}$ \\
\hline Uric acid (mg/dl) & $1.23 \pm 0.01^{\mathrm{a}}$ & $1.29 \pm 0.01^{\mathrm{a}}$ & $1.36 \pm 0.03^{\mathrm{a}}$ & $1.38 \pm 0.01^{\mathrm{a}}$ \\
\hline
\end{tabular}

a Considered significant difference at $p<0.001$ based on ANOVA analysis.

$b$ Considered significant difference at $p<0.05$ compared to control group based on independent samples t-test. 
c Considered insignificant difference at $p<0.05$ compared to control group based on independent samples t-test.

Table (1) referred that the differences between animals donated the five batches and the varients in yield quantity according to buffy coat leukocytes under stress of slaughter and difference in between animals donating different batches and among the same group.

\section{Biochemical Study}

Data presented in table (2) showed the effect of IFN- $\alpha$ Inhalation at different doses on biochemical parameters. Hemoglobin, total proteins, albumin, globulins, total cholesterol,urea and uric acid levels in animals treated with 200,500 and $1000 \mathrm{IU}$ of IFN- $\alpha$ showed a significant increase compared to normal control.

\section{Hematological Study}

Data presented in fig.(1) showed the effect of IFN- $\alpha$ Inhalation at different doses on hematological parameters. Leukocytes, Neutrophils, Eosinophils, Lymphocytes, Monocytes, Basophils and Platelets counts in animals treated with 200,500 and 1000 IFN- $\alpha$ IU showed a significant difference from compared to normal control.

Data presented in table(4)expressed IFN-Y level in male rats subjected to IFN- $\alpha$ inhalation at different doses. IFN- $y$ level in animals treated with IFN- $\alpha$ (200 IU) , (500 IU) and (1000 IU) showed a slight increase compared to control levels.

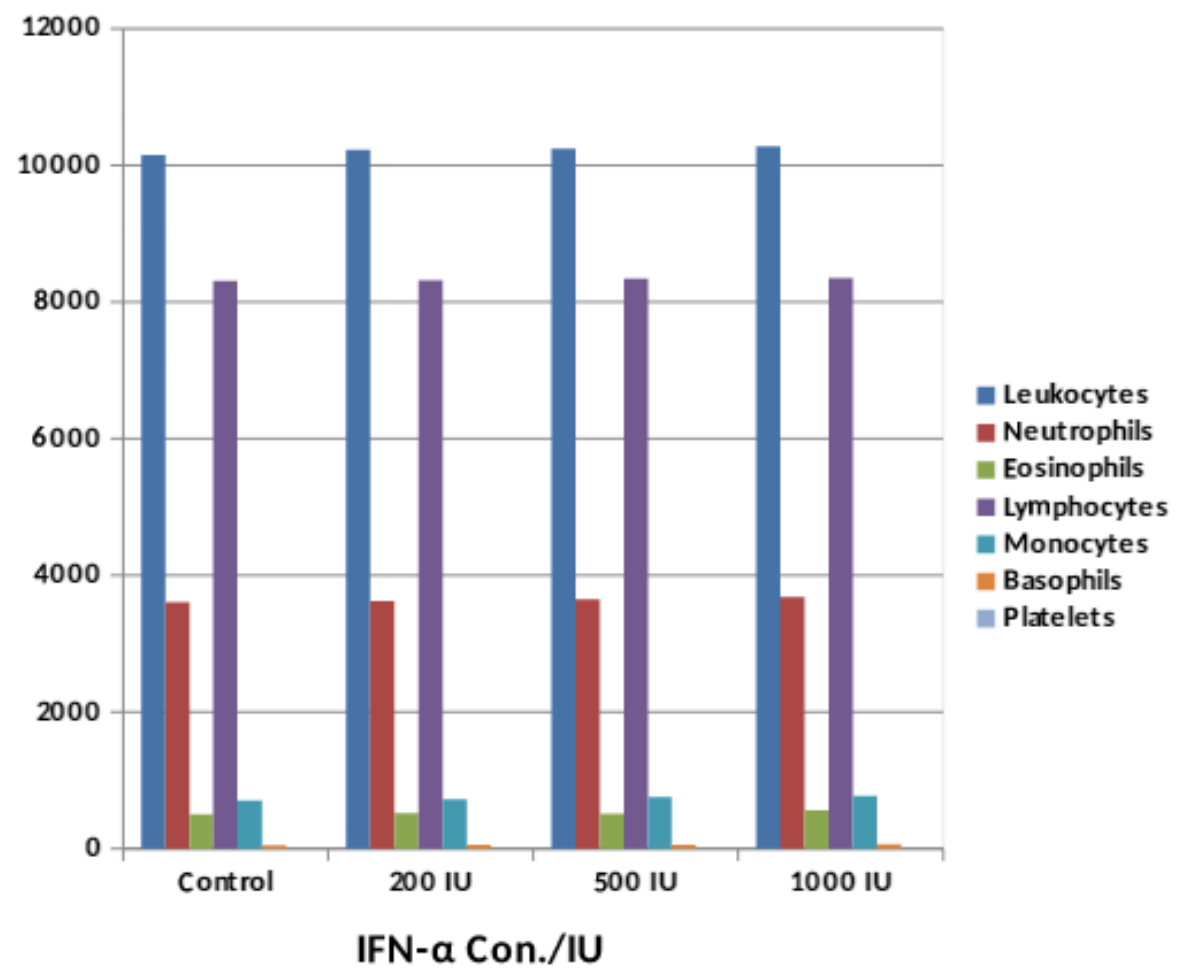

Fig1. Blood parameters of male rats subjected to different concentrations of IFN- $\alpha$ superficial administration. Data are expressed as mean \pm standard deviation. 
Table(4):Determination of IFN- $\gamma$ in male rats subjected to IFN- $\alpha$ inhalation at different doses.

\begin{tabular}{|l|l|l|l|c|}
\hline \multicolumn{1}{|c|}{ Dose } & \multicolumn{1}{c|}{ Control } & \multicolumn{1}{c|}{$\mathbf{2 0 0}$} & \multicolumn{1}{c|}{$\mathbf{5 0 0}$} & $\mathbf{1 0 0 0}$ IFN- \\
& & IFN- $\boldsymbol{\alpha}$ IU & IFN- $\boldsymbol{\alpha}$ IU & $\boldsymbol{\alpha}$ IU \\
\hline $\begin{array}{l}\text { IFN }-\boldsymbol{Y} \text { level } \\
\text { P value }\end{array}$ & $0.091 \pm 0.405$ & $0.108 \pm 0.352$ & $0.091 \pm 0.289$ & $0.092 \pm 0.380$ \\
& & $p=0.94$ & $p=0.99$ & $p=0.96$ \\
\hline
\end{tabular}

Significant difference compared to control level ( $p \leq 0.05)$

IFN- $\alpha$ is a cytokine which has antiviral action and exerts several functions including monocyte/macrophage stimulation and the induction of IFN- $\gamma$ release by $\mathrm{CD}^{+}$Th cells (Brinkmann et al.,1993). IFN- $\alpha$ induces serious side effects when injected systemically, but when aerosolized it does not (Giosuè et al.,1996). IFN- $\alpha$ inhalation, combined with antitubercular chemotherapy, has a favourable effect in patients, in whom pulmonary tuberculosis improvement (Giosuè et al.,1998). Proinflammatory cytokine concentrations decreased concomitantly with disease improvement after aerosolized IFN- $\alpha$ treatment, suggesting a drop in the inflammatory phenomena (Somoskovi et al.,1999). An improvement in pulmonary tuberculosis has also been reported after IFN- $\alpha$ inhalation. In particular, IL-1 $\beta$, IL-6, TNF- $\alpha$ and IFN- $\gamma$ levels dropped after IFN- $\alpha$ treatment. This suggests that the proinflammatory cytokine changes that could be linked to the reduction of the inflammatory processes are associated with disease improvement (Schluger and Rom,1998).

\section{REFERENCES}

Amacher, D.E. et.al. (2005): Use of proteomic methods to identify serum biomarkers associated with rat liver toxicity or hypertrophy. Clin. Chem. 51:1796-1803.

Bleich, A. et al. (2009):CpG motifs of bacterial DNA exert protective effects in mouse models of IBD by antigenindependent tolerance induction. Gastroenterology; 136: 278-287.

Brinkmann, V.; Geiger, T.; Alkan, S.and Heusser, C.H. (1993): Interferon- $\alpha$ increases the frequency of interferon $\mathrm{y}$ producing human CD4+ T cells. J. Exp. Med.; 178: 1655.

Cantell , K. and Hirvonen, S. (1977) :
Preparation of Human Leukocyte Interferon For Clinical Use. Texas Reproduction Biology and Medicine, 35 : 138-140 .

Doumas, B.T. (1975): Clin Chem. 21:1159.

Foster, G. R., Germain, C., Jones, M., Lechler, R. I. and Lombardi, G. ( 2000) : Human T cells elicit IFN-alpha secretion from dendritic cells following cell to cell interactions. Eur. J. Immunol., 30 : 3228-3235.

Giosuè, S.; Casarini, M.; Ameglio, F.; Alemanno, L.; Saltini, C.and Bisetti, A. (1996): Minimal dose of aerosolized interferon-alpha in human subjects: biological consequences and sideeffects. Eur. Respir. J.; 9: 42

Giosuè, S.; Casarini, M.; Alemanno, L.; Galluccio, G.; Mattia, P.; Pedicelli, G.; Rebek, L.; Bisetti, A.and Ameglio, F. (1998): Effects of aerosolized interferon- $\alpha$ in patients with pulmonary tuberculosis. Am. J. Respir. Crit. Care Med. 158: 1156.

Hall, J. A. et al.(2008): Commensal DNA limits regulatory $\mathrm{T}$ cell conversion and is a natural adjuvant of intestinal immune responses. Immunity; 29:637649.

Hermant, P.and Michiels, T. (2014): Interferon- $\lambda$ in the Context of Viral Infections: Production, Response and Therapeutic Implications. J Innate Immun.; Apr. 17

Hofmann, C. et al. (2010):T cell-dependent protective effects of $\mathrm{CpG}$ motifs of bacterial DNA in experimental colitis are mediated by CD11c+ dendritic cells. Gut; 59: 1347-1354.

Huber, J. P. \& Farrar, J. D. (2011): Regulation of effector and memory T-cell functions by type I interferon. Immunology; 132:466-474. 
Rizza, P.1.; Moretti, F. and Belardelli, F.(2010): Recent advances on the immunomodulatory effects of IFNalpha: implications for cancer immunotherapy and autoimmunity. Autoimmunity; 43(3):204-209.

Schluger, N. W.and Rom, W. N. (1998): The host immune response to tuberculosis.) Am. J. Respir. Crit. Care Med., 157: 679.
Somoskovi, A.; Zissel, G.; Zipfel, P. F.; Ziegenhagen, M. W.; Klaucke, J.; Haas, $\mathrm{H}$.; Schlaak, M.and Muller-Quernheim J. (1999): Different cytokine patterns correlate with the extension of disease in pulmonary tuberculosis. Eur. Cytokine Netw. 10: 135.

Szabo, S. J. et al.( 2002): Distinct effects of $\mathrm{T}$ bet in $\mathrm{TH} 1$ lineage commitment and IFN- $y$ production in CD4 and CD8 T cells.Science;295:338-342. 